\title{
SYSTEMATIC DESCRIPTION OF THREE NEW MAMMALS (NOTOUNGULATA AND RODENTIA) FROM THE EARLY MIOCENE CERRO BANDERA FORMATION, NORTHERN PATAGONIA, ARGENTINA
}

\author{
ALEJANDRO G. KRAMARZ ${ }^{1,2}$, MARIANO BOND ${ }^{1,3}$, AND MICHELLE ARNAL ${ }^{1,3}$
}

${ }^{1}$ CONICET.

2Sección Paleontología de Vertebrados, Museo Argentino de Ciencias Naturales "Bernardino Rivadavia", Av. Ángel Gallardo 470, C1405DJR Ciudad Autónoma de Buenos Aires, Buenos Aires, Argentina. agkramarz@macn.gov.ar

32División Paleontología Vertebrados, Museo de La Plata, Paseo del Bosque s/n, B1900FWA La Plata, Buenos Aires, Argentina.constantino1453@yahoo.com.ar; michoarnal@fcnym.unlp.edu.ar

\begin{abstract}
The Cerro Bandera Formation is a mostly pyroclastic continental unit exposed in isolated areas of east-central Neuquén Province, northwestern Patagonia. Several mammals from these deposits were previously reported and support a Colhuehuapian age (early Miocene) for these levels. New findings reveal that this unit bears a much more diverse assemblage and calls into question this age assessment. Here we describe three new species. Protypotherium sinclairisp. nov. (Notoungulata, Interatheriidae) is similar in size to the Santacrucian Protypotherium australe Ameghino, but differs from all the species of the genus by having less reduced p3-p4 talonids. Doryperimys olsacheri gen. et sp. nov. (Rodentia, Neoepiblemidae) has hypselodont, prismatic cheek teeth that combine features of species of Perimys Ameghino and Scotamys antiquus Loomis. The systematic position of Leucokephalos maiorsp. nov. within Caviomorpha is still uncertain, but it is definitively allied to the Deseadan Leucokephalos zeffiae Vucetich, Dozo, Arnal, and Pérez in sharing rooted cheek teeth with an almost identical early occlusal simplification that resembles the 8-shaped configuration of some early octodontoids and putative chinchilloids. The three species co-occur at a single fossil locality and stratigraphic level on the northeastern slope of Barda Negra; P. sinclairi and D. olsacheri are also recorded in other levels exposed in different isolated outcrops of the Cerro Bandera Formation. Doryperimys olsacheri -like other previously described rodents from this unit- is unknown in other presumably coeval mammal associations, but the biochronological and paleobiogeographic meaning of this assemblage is still under study.
\end{abstract}

Key words. Notoungulata. Caviomorpha. Systematics. Cerro Bandera. Early Miocene. Neuquén. Patagonia.

Resumen. DESCRIPCIÓN SISTEMÁTICA DE TRES NUEVOS MAMÍFEROS (NOTOUNGULATA Y RODENTIA) DEL MIOCENO TEMPRANO DE LA FORMACIÓN CERRO BANDERA, NORTE DE PATAGONIA, ARGENTINA. La Formación Cerro Bandera es una unidad continental mayormente piroclástica expuesta en áreas aisladas en el centro-Este de la Provincia de Neuquén, Noroeste de Patagonia. Varios mamíferos de estos depósitos fueron reportados previamente sustentando una Edad Colhuehuapense (Mioceno temprano) para estos niveles. Nuevos hallazgos revelan que esta unidad porta una asociación mucho más diversa y cuestionan esta edad. Aquí se describen tres nuevas especies. Protypotherium sinclairisp. nov. (Notoungulata, Interatheriidae) es similar en tamaño a Protypotherium australe Ameghino (Santacrucense), pero difiere de todas las especies del género por tener los talónidos de p3-p4 menos reducidos. Doryperimys olsacheri gen. et sp. nov. (Rodentia, Neoepiblemidae) tiene molariformes hipselodontes, prismáticos, con caracteres combinados de las especies de Perimys Ameghino y de Scotamys antiquus Loomis. La posición sistemática de Leucokephalos maiorsp. nov. dentro de los Caviomorpha aún es incierta, pero está definitivamente relacionado a Leucokephalos zeffiae Vucetich, Dozo, Arnal, and Pérez (Deseadense) por compartir molarifomes radiculados con una casi idéntica simplificación oclusal temprana que recuerda a la configuración en forma de ocho de algunos octodontoideos tempranos y supuestos chinchilloideos. Las tres especies ocurren positivamente en la misma localidad y nivel estratigráfico en el faldeo nororiental de la Barda Negra; P. sinclairi y D. olsacheri también se registran en otros niveles expuestos en diferentes afloramientos aislados de la Formación Cerro Bandera. Doryperimys olsacheri, así como otros roedores de esta unidad previamente descriptos, es desconocido en otras asociaciones de mamíferos presumiblemente coetáneas, pero el significado biocronológico y paleobiogeográfico de esta asociación aún está bajo estudio.

Palabras clave. Notoungulata. Caviomorpha. Sistemática. Cerro Bandera. Mioceno temprano. Neuquén. Patagonia.

THE Cerro Bandera Formation is a Cenozoic continental sedimentary succession exposed in isolated areas of eastcentral Neuquén Province, northwestern Patagonia (Fig. 1).
These outcrops represent the relicts of an old alluvial infilling developed in small local valleys eroded into Late Cretaceous and Paleocene rocks (Leanza and Hugo, 1997; 
Kramarz et al., 2005). This unit yielded a diverse mammal assemblage and a few bird remains (Kramarz et al., 2005). Based upon the presumed correlation with the nearby Chichinales Formation suggested by Leanza and Hugo (1997) and the occurrence of some particular mammal taxa (e.g., Cramauchenia normalis Ameghino, 1902; Proadinotherium cf. P. muensteri Ameghino, 1902; Eosteiromys Ameghino, 1902; Caviocricetus lucasi Vucetich and Verzi, 1996), Kramarz et al. (2005) concluded that the fossilbearing deposits of the Cerro Bandera Formation correlate with the Lower Faunal Zone in the Colhue Huapi Member of the Sarmiento Formation at Gran Barranca (south of Colhue Huapi Lake, central Patagonia), dated at 21.1-20.1 Ma (Dunn et al., 2013), the type section for the Colhuehuapian
South American Land Mammal Age (SALMA).

Additional taxa in new localities of the Cerro Bandera Formation were further reported by Kramarz (2005), Kramarz and Bond (2011), Kramarz and Paz (2013), and Kramarz et al. (2011, 2012), but were not fully described or investigated.

The aim of this contribution is to describe new mammal taxa from the Cerro Bandera Formation, based on recently collected specimens and/or previously reported specimens (Kramarz et al., 2005) that still lack formal naming. These descriptions expand knowledge of the mammal diversity preserved in this unit allowing for further discussion of its correlation with other early Miocene mammal-bearing deposits in South America.
(1)

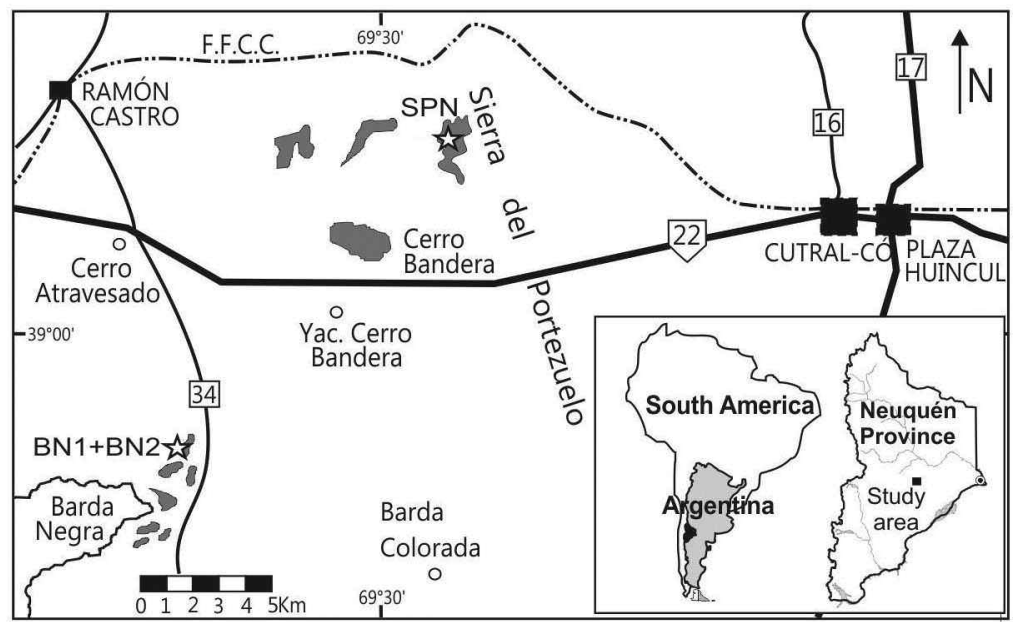

\section{References}

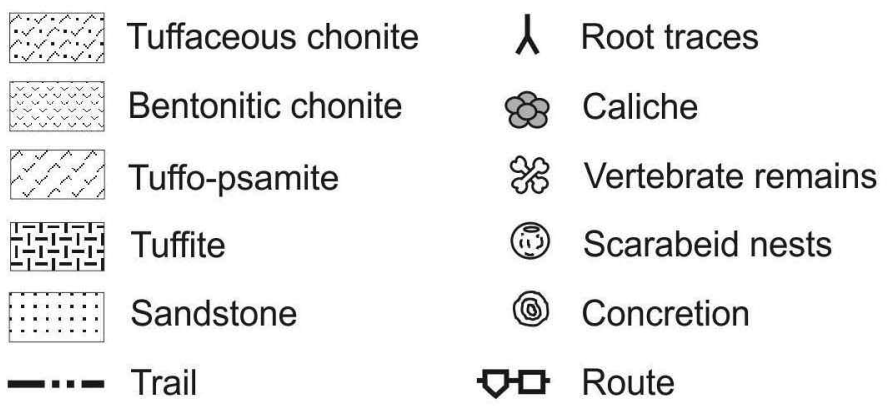

(2)

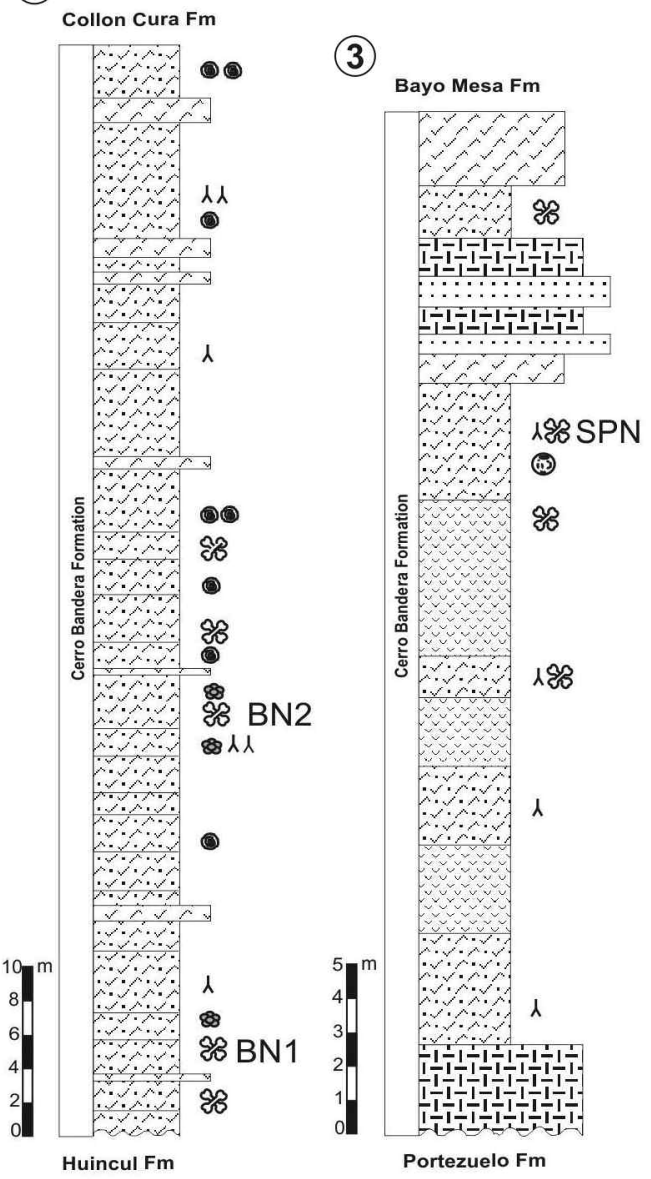

Figure 1. Geographic and stratigraphic provenance of the specimens described in this paper. 1, Geographic location of the exposures of the Cerro Bandera Formation (grey areas) in central Neuquén Province. White stars show the location of the fossil localities. $\mathbf{2}$, Stratigraphic section of the Cerro Bandera Formation on the northeastern slope of Barda Negra showing the stratigraphic position of the mammal-bearing horizons exposed at BN1 and BN2. 3, Stratigraphic section of the Cerro Bandera Formation at the northwestern slope of Sierra del Portezuelo Norte showing the stratigraphic position of the mammal-bearing horizon exposed at SPN. Modified from Kramarz et al. (2005, 2011). 
Institutional abbreviations. MACN, Museo Argentino de Ciencias Naturales "Bernardino Rivadavia", Ciudad Autónoma de Buenos Aires, Buenos Aires, Argentina; MLP, Museo de La Plata, Buenos Aires, Argentina; MOZ-PV, Colección de Paleovertebrados, Museo Provincial de Ciencias Naturales "Dr. Prof. Juan A. Olsacher", Zapala, Neuquén, Argentina; MPEF, Museo Paleontológico Egidio Feruglio, Trelew, Chubut, Argentina; PVPH, Colección Paleontología de Vertebrados, Museo Municipal Carmen Funes, Plaza Huincul, Neuquén, Argentina.

\section{GEOLOGICAL SETTING AND FOSSIL LOCALITIES}

The Cerro Bandera Formation is $45 \mathrm{~m}$-thick and consists of pyroclastic deposits showing evidence of fluvial reworking and/or pedogenesis, alternating with primary fall-out pyroclastic deposits, with abundant bentonitic horizons in the lower section and scant intercalated sandstones in the upper section. The abundant tuffaceous and tuffitic contents would have originated from discontinuous ash fall derived from Andean or sub-Andean volcanic centers. The origin of these deposits is associated with a fluvial environment in an intermontane foreland basin; lacustrine deposits accumulated in the central, topographically lower areas of the paleovalleys, whereas paleosols accumulated in the marginal, higher areas. This depositional system resulted in marked lateral facies variations among the currently isolated exposures (Leanza and Hugo, 1997; Kramarz et al., 2005).

Several isolated outcrops of the Cerro Bandera Formation bearing vertebrate remains were identified in east-central Neuquén Province (Fig. 1). The fossils studied herein are derived from exposures located along the northeastern slope of Barda Negra and the northwestern slope of Sierra del Portezuelo Norte. In Barda Negra Locality 1 (Loc. BN1, Fig. 1.1) (3902'06.3" S; $\left.69^{\circ} 40^{\prime} 54.3^{\prime \prime} \mathrm{W}\right)$, mammal remains come from whitish-greyish tuffaceous horizons, about six meters from the base of the stratigraphic section exposed in the area (Fig. 1.2). A second site at Barda Negra (Locality BN2) (39 $02^{\prime} 09.4^{\prime \prime} \mathrm{S} ; 69^{\circ} 40^{\prime} 47.6^{\prime \prime} \mathrm{W}$ ) is represented by similar rocks located nearly $25 \mathrm{~m}$ from the exposed base (Fig. 1.2). In Sierra del Portezuelo Norte (Loc. SPN, Fig. 1.1) (38 52' 52" S; 69² 28' 22" W), the level bearing the remains described herein is a pedogenized tuffaceous chonite (sensu Teruggi et al., 1978) with poorly preserved scarabeid nests, about $21 \mathrm{~m}$ from the base of the stratigraphic section exposed in the area (Fig. 1.3).

\section{SYSTEMATIC PALEONTOLOGY}

\section{Order Notoungulata Roth, 1903}

Family INTERATHERIIDAE Ameghino, 1887a

Genus Protypotherium Ameghino, 1885

Type species. Protypotherium antiquum Ameghino, 1885.

Included species. P. attenuatum Ameghino, 1887a; P. praerutilum Ameghino, 1887a; P. australe Ameghino, 1887b; P. diastematum (Ameghino, 1891); P. distinctum Cabrera and Kraglievich, 1931; and P. minutus Cabrera and Kraglievich, 1931.

Chronological and geographic distribution. Early-late Miocene, Patagonia (Chile and Argentina), central Argentina, and Bolivia (Ameghino, 1885, 1887a; Cione et al., 2000; Flynn et al., 2002, 2008; Croft et al., 2009).

\section{Protypotherium sinclairisp. nov.}

Figure 2, Table 1

1984 Protypotherium sp.; Vucetich and Bond, p. 105. 2005 Protypotherium sp.; Kramarz et al., p. 282, fig. 4A.

Holotype. PVPH 352, partial right mandibular ramus with i2m2 (Loc. SPN).

Etymology. After the paleontologist William J. Sinclair, in recognition of his substantial contributions to the knowledge of Miocene typotheres systematics.

Referred specimens and provenance. MOZ-PV 899, right mandibular fragment with p3-p4 (Loc. BN1); MOZ-PV 1034, left mandibular fragment with p2-p3 (Loc. BN2); MLP 75-II5-8, right mandibular fragment with p2-m3 (see discussion below).

Diagnosis. Interatheriid with talonids of p3-p4 shorter (mesiodistally) than the trigonid, as in all species of Protypotherium and Miocochilius anomopodus Stirton, 1953, and unlike the species of Cochilius Ameghino, 1902 and Interatherium Ameghino, 1887b. Differs from M. anomopodus by lacking diastemata between c, p1, and p2. Differs from all the species of Protypotherium by having a more elongate p2 with more pronounced labial and lingual flexids, and transversely larger p3-p4 talonids that are almost as wide as the trigonids. Size similar to $P$. australe, larger than $P$. praerutilum and much larger than $P$. attenuatum. 

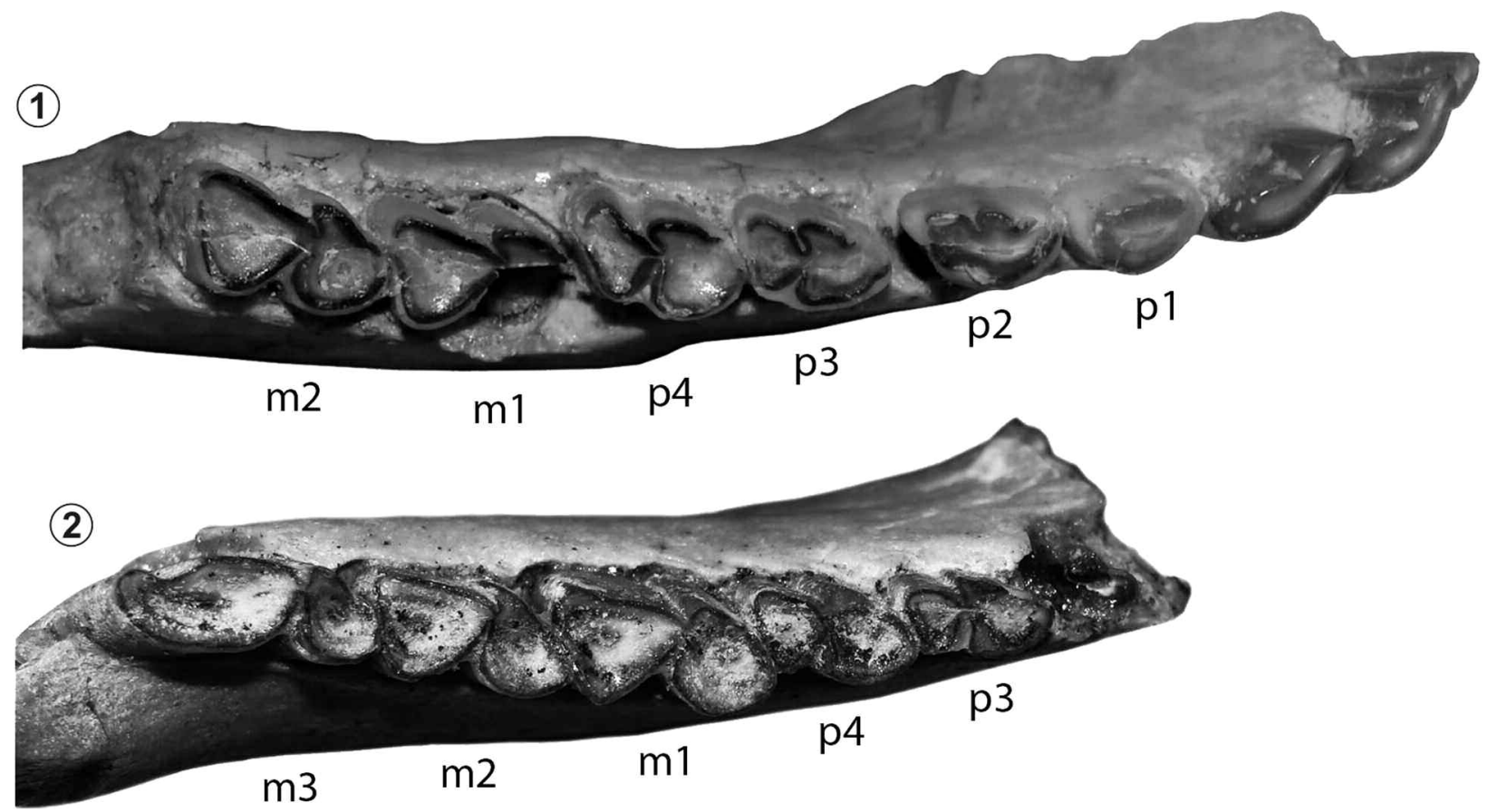

(3)

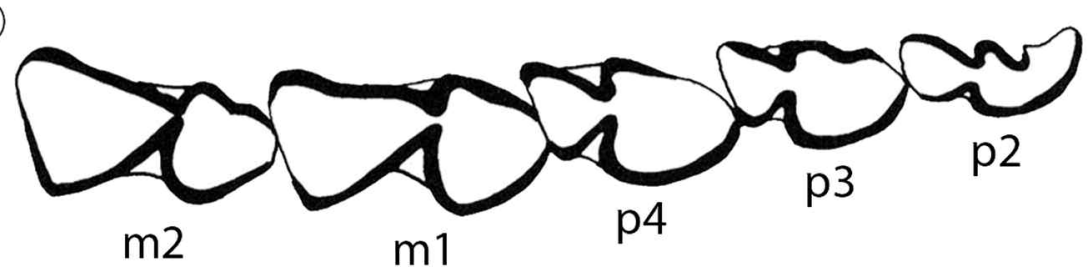

Figure 2. Comparison of lower dentitions of Protypotherium sinclairi sp. nov. and Protypotherium australe Ameghino. 1, Protypotherium sinclairi sp. nov., PVPH 352 (holotype), right mandibular ramus with i2-m2 in occlusal view; 2, MLP 75-II-5-8, right mandibular ramus with p3-m3 in occlusal view; 3, Protypotherium australe, schematic occlusal view of the $\mathrm{p} 2-\mathrm{m} 2$ series (modified from Tauber, 1996). Abbreviations: $\mathrm{m}$, lower molar; p, lower premolar. Scale bar $=5 \mathrm{~mm}$.

TABLE 1. Dental measurements (in $\mathrm{mm}$ ) of Protypotherium sinclairi sp. nov.

\begin{tabular}{|c|c|c|c|c|c|c|c|c|c|c|c|c|c|c|c|c|c|c|c|c|c|c|c|}
\hline & $i$ & 2 & $i$ & $i 3$ & $c$ & & $p$ & & $p$ & 2 & & p3 & & & p4 & & & $m 1$ & & & $m 2$ & & $i 2-m 2$ \\
\hline & $L$ & $w$ & $L$ & $w$ & $L$ & $w$ & $L$ & $w$ & $L$ & $w$ & $L$ & TalW & TriW & $L$ & TalW & TriW & $L$ & TalW & V TriW & $L$ & TalW & TriW & length \\
\hline PVPH 352 & 3.2 & 2.3 & 5.3 & 2.5 & 5.4 & 2.4 & 5.1 & 3.1 & 5.7 & 3.3 & 5.3 & 3.4 & 2.9 & 6.3 & 3.8 & 3.8 & $6.7^{*}$ & & 4.4 & 6.9 & 4.3 & 4.5 & 46.1 \\
\hline MOZ-PV 899 & & & & & & & & & & & 5.2 & 3.3 & 2.7 & 5.7 & 3.2 & 3.1 & & & & & & & \\
\hline MOZ-PV 1034 & & & & & & & & & 4.1 & 2.5 & 5.6 & 2.8 & 2.6 & & & & & & & & & & \\
\hline MLP 75-II-5-8 & & & & & & & & & & & 5.2 & 2.9 & 2.6 & 5.4 & 3.7 & 3 & 7.5 & 3.9 & 4.2 & 7.1 & 3.8 & 3.8 & \\
\hline
\end{tabular}

Abbreviations: c, lower canine; i, lower incisor; L, total preserved length; $m$, lower molar; $p$, lower premolar; TalW, talonid width; TriW, trigonid width; $W$, maximum preserved width; * approximate.

\section{Discussion}

The features of the lower premolars mentioned in the diagnosis are clearly distinct from those of other interathere species and are constant among the referred specimens. Contrarily, other characters of the incisors, molars and mandible seem to vary greatly among specimens referred 
to this and other species of Protypotherium. Further comparisons could eventually support the inclusion of additional characters in the diagnosis.

The taxonomic status of the numerous species of Protypotherium and other interatheriines was discussed by Sinclair (1909) and later by Tauber (1996) (see Tab. 2), although a few species based on materials that cannot be compared with $P$. sinclairi (i.e., upper cheek teeth) remain unresolved and deserve the following comments.

Protypotherium diversidens Ameghino, 1891, is based on a juvenile maxillary with the deciduous premolars and M1-M2 (MACN A 4052). The size of the preserved M1 (length $=5.7 \mathrm{~mm}$, width $=3.4 \mathrm{~mm}$ ) is very similar to that of $P$. attenuatum (see Tauber, 1996, p. 22), much smaller than in $P$. australe, and consequently also smaller than the inferred size of $P$. sinclairi. Tentatively, we herein propose $P$. diver- sidens as a junior synonym of $P$. attenuatum.

Protypotherium diastematum is based on a palate (MACN A 4044) with a small diastema between P1 and P2 (Ameghino, 1891). We found a similar condition in specimens referred to other species, but the actual distribution, variability and systematic relevance of this feature is still uncertain for us, and thus we prefer to keep $P$. diastematum as a valid species for the time being. The size of $P$. diastematum (M1-M3 length= $18.8 \mathrm{~mm}$ ) is definitively smaller than in P. australe (see Sinclair, 1909, p. 35), and therefore smaller than $P$. sinclairi.

Protypotherium martini Lane, 1927, is also based on a maxilla. According to Lane (1927) it differs from other species of Protypotherium by having more elongated upper cheek teeth. However, the type of Protypotherium compressidens Ameghino, 1891 (MACN A 4029-4030), inter-

TABLE 2. Species of Protypotherium and their corresponding synonyms.

\begin{tabular}{|c|c|c|c|}
\hline Species & Synonyms & Source & Age \\
\hline P. antiquum Ameghino, 1885 & - & & Huayquerian or Chasicoan \\
\hline P. distinctum Cabrera and Kraglievich, 1931 & - & & Chasicoan \\
\hline P. minutus Cabrera and Kraglievich, 1931 & - & & Chasicoan \\
\hline \multirow{6}{*}{ P. australe Ameghino, $1887 \mathrm{~b}$} & P. palmidens (Ameghino, 1889) & Sinclair, 1909 & Santacrucian \\
\hline & P. furculosus (Ameghino, 1891) & Sinclair, 1909 & Santacrucian \\
\hline & P. distortus (Ameghino, 1891) & Sinclair, 1909 & Santacrucian \\
\hline & P. altus (Ameghino, 1891) & Sinclair, 1909 & Santacrucian \\
\hline & P. lineare Ameghino, 1894 & Sinclair, 1909 & Santacrucian \\
\hline & P. claudum Ameghino, 1889 & Tauber, 1996 & Santacrucian \\
\hline \multirow{4}{*}{ P. praerutilum Ameghino, $1887 a$} & P. compressidens Ameghino, 1891 & Sinclair, 1909 & Santacrucian \\
\hline & P. convexidens Ameghino, 1891 & Sinclair, 1909 & Santacrucian \\
\hline & P. leptocephalus (Ameghino, 1891) & Sinclair, 1909 & Santacrucian \\
\hline & P. martini Lane, 1927 & This paper & Santacrucian \\
\hline \multirow{4}{*}{ P. attenuatum Ameghino, $1887 a$} & P. globossum Ameghino, 1891 & Sinclair, 1909 & Santacrucian \\
\hline & P. icochiloides (Ameghino, 1894) & Sinclair, 1909 & Santacrucian \\
\hline & P. rectus (Ameghino, 1891) & Sinclair, 1909 & Santacrucian \\
\hline & P. diversidens Ameghino, 1891 & This paper & Santacrucian \\
\hline P. diastematum Ameghino, 1891 & - & & Santacrucian \\
\hline P. sinclairi sp. nov. & - & This paper & Colhuehuapian? \\
\hline P. minor Bordas, 1939 & Cochilius minor (Bordas, 1939) & This paper & Colhuehuapian \\
\hline
\end{tabular}


preted by Sinclair (1909) and by Tauber (1996) as a junior synonym of $P$. praerutilum, has even more elongated upper cheek teeth. Consequently, P. martini should be considered a junior synonym of $P$. praerutilum. Alternatively, $P$. compressidens and $P$. martini could be united in a separate species in which the lower premolars (preserved in the holotype of $P$. compressidens) differ definitively from those of $P$. sinclairi (i.e., talonids more reduced transversely).

Protypotherium minor Bordas, 1939, based on a partial skull with dentition (MACN Pv 11742), is the only species of Protypotherium described from deposits bearing Colhuehuapian mammals. The upper premolars of the type and only known specimen are clearly bilobed with no reduction of the anterior lobe, a feature that characterizes species of Protypotherium. Therefore, P. minor is more properly referable to the genus Cochilius.

In the holotype of Protypotherium claudum Ameghino, 1889 (MACN A 551), interpreted as a junior synonym of $P$. australe by Tauber (1996), the talonids of p3-p4 are almost as wide as the trigonids, as in P. sinclairi. However, the premolars are vaguely molariform, structurally very different from those of $P$. sinclairi and other recognized species: the lingual column of the metaconid is much less prominent, the talonids are much shorter distolingually, the p3 lacks a lingual flexid, and the p4 lingual flexid is much more superficial. Protypotherium claudum is positively distinct from $P$. sinclairi, either as a separate species or as a synonym of $P$. australe.

The premolar morphology of MLP 75-II-5-8 (Fig. 2.2), here referred to $P$. sinclairi, is definitively closer to that of the holotype than to any other currently known specimen of Protypotherium. It comes from the Sarmiento Formation exposed along the southern cliffs of the Chubut River at Bryn Gwyn, in central Patagonia. The bearing horizon, which also provided the holotype of Gaimanomys alwinea Vucetich and Bond, 1984, is a light grey sandstone near the top of the Sarmiento Formation (Trelew Member), overlying beds bearing Colhuehuapian mammals and underlying the marine Gaiman Formation. This finding documents that $P$. sinclairihad a wide distribution in Patagonia.

Specimen PVPH 351 from the Cerro Bandera Formation (Loc. SPN) was listed by Kramarz et al. (2005) as co-specific with the specimen herein selected as holotype of $P$. sinclairi and was interpreted as having deciduous premolars.
Nevertheless, a further analysis revealed that at least the p3 and p4 of PVPH 351 are rootless (i.e., they are not deciduous) and do not show the reduced talonids typical of Protypotherium. Therefore, this specimen could more likely belong to some species of Cochilius.

Order Rodentia Bowdich, 1821

Suborder HystricognatHI Tullberg, 1899

Family NeoepIBLEMIDAE Kraglievich, 1926

Genus Doryperimys gen. nov.

Type species. Doryperimys olsacheri sp. nov.

Etymology. Dory, from the Greek "spear," in relation to the spear-like cross section of the cheek teeth, and Perimys Ameghino, 1887a, an early Miocene chinchilloid.

Chronological and geographic distribution. Early Miocene, Colhuehuapian? SALMA; Neuquén Province, Argentina.

Diagnosis. Small neoepiblemid, size similar to adult specimens of Perimys incavatus Ameghino, 1902, with hypselodont, biprismatic cheek teeth (triprismatic in M3), with wide interprismatic cement. Differs from species of Perimys by having the following combination of characters: cheek teeth formed by comparatively broader prisms; labial apexes of the lower cheek tooth prisms much sharper (more lanceolate occlusal contour); posterior prism of m1-m2 much more extended lingually than the anterior one; lingual flexid more penetrating in $\mathrm{m} 1$ than in $\mathrm{m} 3$ (in contrast to species of Perimys); enamel remnant covering the labialmost portion of the anterior wall of the lower molars and the lingualmost portion of the posterior wall of the upper ones.

\section{Doryperimys olsacheri sp. nov.}

Figure 3, Table 3

Holotype. MOZ-PV 955, a right mandibular fragment with p4-m3 (Loc. BN1).

Hypodigm. The holotype and the following specimens: MOZPV 956, right maxillary fragment with M1-M2 (Loc. BN1); MOZ-PV 957, right mandibular fragment with erupting $\mathrm{p} 4$, m1-m2 (Loc. BN1); MOZ-PV 958, partial left m1 or m2 (Loc. BN1); MOZ-PV 959, left m1 or m2 (Loc. BN1); MOZ-PV 960, right m1 or m2 (Loc. BN1); MOZ-PV 961, left p4 (Loc. BN1); MOZ-PV 962, right M1 or M2 (Loc. BN1); MOZ-PV 963, right 


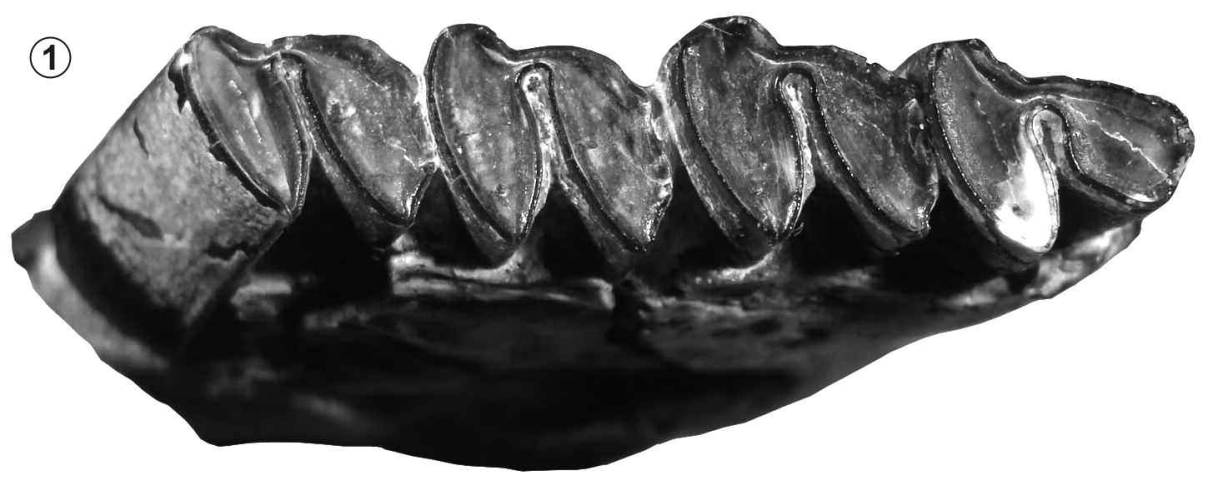

(2)

(3)

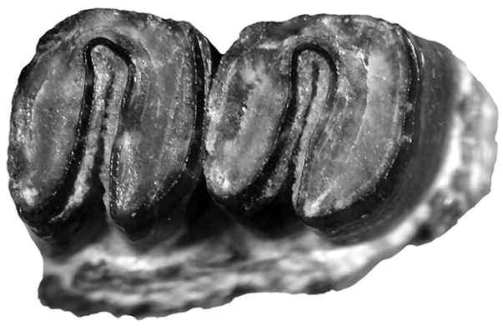

(4)

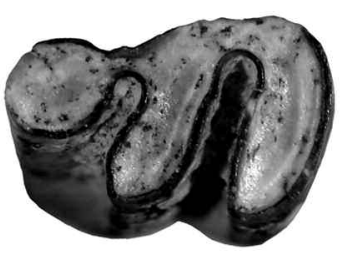

Figure 3. Doryperimys olsacheri sp. nov. 1, MOZ-PV 955 (holotype), right p4-m3 in occlusal view; 2, M0Z-PV 1047, right m3 in occlusal view; 3, MOZ-PV 956, right M1-M2 in occlusal view; 4, MOZ-PV 988, right M3 in occlusal view. Scale bar= 5 mm.

TABLE 3. Dental measurements (in $\mathrm{mm}$ ) of Doryperimys olsacheri gen. et sp. nov.

\begin{tabular}{|c|c|c|c|c|c|c|c|c|c|c|c|c|c|c|c|c|}
\hline & & $p 4$ & & & $m 1$ & & & $m 2$ & & & 1 or $m$ & & & $m 3$ & & $p 4-m 3$ \\
\hline & $L$ & $A W$ & $P W$ & $L$ & $A W$ & $P W$ & $L$ & $A W$ & $P W$ & $L$ & $A W$ & $P W$ & $L$ & $A W$ & $P W$ & length \\
\hline MOZ-PV 955 & 5.2 & 2.3 & 4 & 5.1 & 3.6 & 4.4 & 5 & 4 & 4.5 & & & & 5.1 & 3.8 & 3.9 & 20.1 \\
\hline MOZ-PV 959 & & & & & & & & & & 4.4 & 3.6 & 3.5 & & & & \\
\hline MOZ-PV 961 & 3.8 & 2.1 & 3.1 & & & & & & & & & & & & & \\
\hline MOZ-PV 1407 & & & & & & & & & & & & 3.9 & 3.1 & 3 & & \\
\hline MOZ-PV 957 & & & & & & & 3.9 & 3 & 3.1 & & & & & & & \\
\hline MOZ-PV 987 & & & & & & & & & & 4.8 & 4 & 4 & & & & \\
\hline MOZ-PV 960 & & & & & & & & & & 5 & 3.5 & 3.5 & & & & \\
\hline MOZ-PV 1046 & & & & & & & & & & & & 4.8 & 4.3 & 3.8 & & \\
\hline \multirow[t]{3}{*}{ MOZ-PV 984} & 4.1 & & 3.3 & 4.4 & 3.3 & 3.9 & & & & & & & & & & \\
\hline & & & & & M1 & & & M2 & & & 11 or $M$ & & & & & \\
\hline & & & & $L$ & $A W$ & $P W$ & $L$ & $A W$ & $P W$ & $L$ & $A W$ & $P W$ & $L$ & $A W$ & $P W$ & $3 W$ \\
\hline MOZ-PV 956 & & & & 4 & 4 & 3.6 & 3.7 & 4.1 & 4.1 & & & & & & & \\
\hline MOZ-PV 962 & & & & & & & & & & 3.8 & 4.1 & 3.6 & & & & \\
\hline MOZ-PV 988 & & & & & & & & & & & & & 6.3 & 3.9 & 3.6 & 1.9 \\
\hline MOZ-PV 963 & & & & & & & & & & & & & & & 3.3 & 1.8 \\
\hline
\end{tabular}

Abbreviations: AW, anterior prism maximum preserved width; $L$, total preserved length; $m$, lower molar; $M$, upper molar; $p$, lower premolar; $P W$, posterior prism maximum preserved width; $3 W$, third prism of $M 3$ maximum preserved width. 
M3 (Loc. BN1); MOZ-PV 984, right mandibular fragment with p4-m2 (Loc. BN2); MOZ-PV 986, right m1 or m2 (Loc. BN2); MOZ-PV 987, left m1 or m2 (Loc. BN2); MOZ-PV 988, isolated right M3 (Loc. BN2); MOZ-PV 989, left M3 (Loc. BN2); MOZ-PV 1046, left m1 or m2 (Loc. BN1); MOZ-PV 1047, right m3? (juvenile) (Loc. BN1).

Etymology. In acknowledgement of the Museum "Dr. Prof. Juan A. Olsacher" of Zapala, Neuquén, whose staff collaborated kindly with our project during field trips to Cenozoic localities in Neuquén Province.

Diagnosis. As for the genus.

Description and comparisons. All cheek teeth (Fig. 3.1-4) are hypselodont (high crowned and rootless), biprismatic (triprismatic on M3), with a thin isthmus (labial in the uppers, lingual in the lowers) connecting the prisms. Cement fills the lingual (and narrowest) portion of the interprismatic spaces (hypoflexid), and partially covers the labial portion of their internal walls. A thin layer of cement also irregularly covers the external walls of the crowns.

The prisms of the lower molars (Fig. 3.1-2) have convex anterior and posterior walls, sharp labial apexes and rounded lingual sides. Thus, the occlusal outline is strongly spear-like or lanceolate, with the main transverse diameter somewhat oblique anterolabial-posterolingually. The posterior prism extends further lingually than the anterior one, and thus the lingual wall of each tooth is inflected in front of the lingual aspect of the posterior prism. This inflection is more pronounced on $\mathrm{m} 1$ than on $\mathrm{m} 3$. Enamel surrounds the crown, except for: a) a thin vertical band on the lingual tip of the posterior prisms, and b) the central part of the anterior wall of the anterior prisms, where the crown contacts the preceding tooth. Interestingly, there is a vestige of enamel covering on the labialmost part of the anterior wall, absent in all species of Perimys and in Scotamys antiquus Loomis, 1914. A probable m3, MOZ-PV 1047 (Fig. 3.2), preserves a small, rounded enamel lake on the lingual portion of the posterior prism, posterior to the hypoflexus, very likely corresponding to the metafossettid. Unlike in the holotype and other specimens lacking enamel lakes, the lingual inflection in this tooth is inconspicuous on the occlusal surface but much more pronounced when viewed from the base. Therefore, the lingual inflection is not homologous with the metaflexid, but rather is a secondary inflection of the lingual wall that becomes deeper with age, as in species of Perimys (Kramarz, 2002, p. 173). The p4 (Fig. 3.1) is essentially as the molars, but the anterior prism is irregularly rhomboidal, much shorter transversely than the posterior prism. The labial portions of the internal walls of the hypoflexid are more divergent than in the molars. The enamel is absent in a thin vertical band on the anterior aspect of the anterior prism.

No upper premolar has been recovered. In the upper molars referred to this species (Fig. 3.3), the lingual apexes are less sharp, and the internal walls of the hypoflexus are less divergent than in the lower ones. Thus, the lanceolate outline of the prisms is less pronounced, but more than in upper molars of species of Perimys. The enamel is much reduced or absent on the entire labial wall and on the posterior wall of the posterior prism, except on its lingualmost portion. The M3 tentatively referred to this species (Fig. 3.4) is typically triprismatic, as in all species of Perimys, but the two anterior prisms are vaguely lanceolate, less than in M1 and M2, but definitively more than in M3 of Perimys. The third prism is sub-circular in outline and transversely very short (nearly $50 \%$ of the transverse extension of the second prism). The isthmus connecting the second and third prisms is comparatively broader. Enamel is absent from the labial aspect of the two anterior prisms and the isthmus connecting them, as well as on the posterior wall of the third prism; therefore, the single enamel band on the labial wall of the tooth is comparatively broader than in all the species of Perimys.

The mandibular portion preserved in the holotype shows similar anatomy to that of Perimys: The diastema in front of the p4 is lower than the alveolar line, the mental foramen opens laterally, the notch for the tendon of the masseter medialis pars infraorbitalis is below $\mathrm{m} 1$ and continuous with the masseteric crest, the alveolus for the incisor runs medial to the tooth row, and its bottom is below m1-m2.

\section{Discussion}

Perimys, with 21 described species, was among the most abundant and diverse caviomorph rodents during Colhuehuapian and Santacrucian times. According to Scott (1905, p. 433), Perimys "...includes a surprising number of species, which, in size, range from very small animals to the largest rodents yet found in the [Santa Cruz] formation." Taxonomic identification of these species is extremely difficult because 
the characters supporting the nominal species (mostly dental characters) are usually inconsistently distributed within a given sample. Recent revisions concluded that such characters represent different ontogenetic stages and/or mere individual variation within very few taxa (Kramarz, 2002; Vucetich et al., 2010). Doryperimys olsacheri shares with species of Perimys the well defined lingual flexids on the lower molars, a distinct third lobe on M3, and a short lower incisor. However, D. olsacheri is clearly distinct from all species of Perimys by having less reduced enamel (e.g., on the labial tip of the anterior wall of the anterior prism) and, particularly, by the lanceolate cross section of the prisms. In fact, the general appearance of the cheek teeth series of the holotype superficially resembles that of some basal cavioids (i.e., "eocardiids"). Nevertheless, in "eocardiids" the prisms are mainly transverse instead of oblique, and the enamel is not reduced on the anterior wall of the lower molars (nor the posterior wall of the upper ones). Other distinct features are suggestively shared with the Deseadan (late Oligocene) S. antiquus: hypoflexid narrower lingually than labially, posterior prism of lower molars transversely wider than the anterior prism, third lobe of M3 much narrower than the anterior prisms, and cement filling only the internal part of the interprismatic spaces. Owing to this particular combination of characters, we prefer herein to erect a new genus to include this new species instead of assigning it to Perimys (or Scotamys), although assessment of the systematic meaning of all these characters is pending further cladistic analysis.

\section{CAVIOMORPHA incertae sedis}

Genus Leucokephalos Vucetich, Dozo, Arnal, and Pérez, 2014

Type species. Leucokephalos zeffiae Vucetich, Dozo, Arnal, and Pérez, 2014.

Chronological and geographic distribution. Late Oligoceneearly Miocene. Chubut and Neuquén provinces, Argentina.

\section{Leucokephalos maior sp. nov.}

Figure 4, Table 4

Holotype. MOZ-PV 969, partial left mandible with i, p4-m2 (Loc BN1).
Etymology. From Latin maior= greater, in reference to its size larger than the type species.

Diagnosis. Nearly 35\% larger than the type species. Metalophulid II of p4 more curved, labial apex of hypoconid on p4m3 sharper.

Description and comparisons. The cheek teeth are rooted. The preserved portions of the crowns are longer than high (Fig. 4.2), suggesting that the teeth were moderately worn and relatively low-crowned with very ephemeral fossettids, rather than very worn and high-crowned with relatively persistent fossettids. The occlusal surfaces are almost flat (not terraced), although on the p4 the occlusal plane of the trigonid is somewhat higher than the talonid (Fig. 4.2), very likely due to differential wear. The enamel covering is uniform around the crowns.

The p4 (Fig. 4.1) is longer than wide, proportionally longer than in the type species. On the trigonid, a small, ovoid anterofossetid separates the transverse metalophulid I from the metalophulid II, which curves forward to
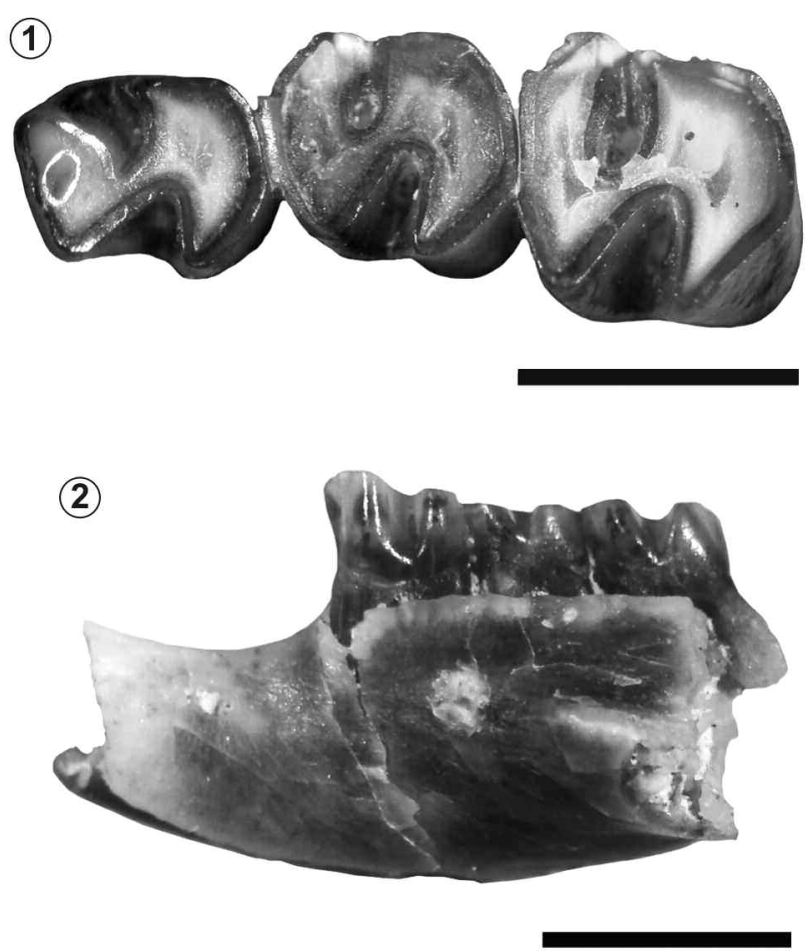

Figure 4. Leucokephalos maior sp. nov., MOZ-PV 969, holotype. 1, left $\mathrm{p} 4-\mathrm{m} 2$ in occlusal view; 2 , left mandible in lateral view. Scale bar= 3 $\mathrm{mm}$ in $1,5 \mathrm{~mm}$ in 2 . 
TABLE 4. Compared dental measurements (in $\mathrm{mm}$ ) of Leucokephalos spp.

\begin{tabular}{|c|c|c|c|c|c|c|c|c|c|c|}
\hline & & & $p 4$ & & & $m 1$ & & & $m 2$ & \\
\hline & & $L$ & $A W$ & $P W$ & $L$ & $A W$ & $P W$ & $L$ & $A W$ & $P W$ \\
\hline Leucokephalos maior sp. nov. & MPEF-PV 583 & 2.55 & 1.70 & 2.1 & 2.55 & 2.28 & 2.42 & 2.95 & 2.88 & 2.62 \\
\hline Leucokephalos zeffiae Vucetich et al. 2014 & $\begin{array}{l}\text { MOZ-PV } 969 \\
\text { (Holotype) }\end{array}$ & 1.81 & 1.55 & 1.70 & 1.88 & 1.66 & 1.70 & 2.03 & 2.15 & 2.07 \\
\hline
\end{tabular}

Abbreviations: AW, anterior preserved width; $L$, total preserved length; $m$, lower molar; $p$, lower premolar; PW, posterior preserved width.

contact the metaconid. In the holotype of L. zeffiae and some referred specimens (Vucetich et al., 2014: figs. 5F-H), the metalophulid II is indistinct, but according to the geometry of the lingual flexid, this lophid seems to be straighter than in $L$. maior, whereas in the less worn specimen referred to $L$. zeffiae by Vucetich et al. (2014) (MPEF PV 585, Vucetich et al., 2014: fig. 5E), the metalophulid II points to the entoconid and does not contact the metaconid. The talonid is a simple lobe, wider than the trigonid, with a straight lingual wall and a sharp labial apex. There is a small anterior projection of the lingual wall of the talonid, suggesting the presence of a moderate anterior arm of the entoconid. This structure is not discernible in the holotype of $L$. zeffiae, but is visible in the referred specimen, MPEF PV 586 (see Vucetich et al., 2014: fig. 5F). The ectolophid is thin and oblique, connecting the protoconid with the central portion of the talonid. The lingual flexid (mesoflexid?) and the hypoflexid are subtriangular and penetrate almost up to the midpoint of the transverse diameter of the crown.

The $\mathrm{m} 1$ (Fig. 4.1) is sub-rounded in occlusal view due to the markedly convex anterior and posterior walls. The only features preserved on the occlusal surface are a very penetrating hypoflexid (also reaching the middle of the transverse diameter) and a transverse lingual flexid on the anterior half of the crown (anterior to the hypoflexid). The resulting occlusal design is vaguely octodontiform, as in the m1 of MPEF PV 584, referred to L. zeffiae by Vucetich et al. (2014: fig. 5G).

The m2 (Fig. 4.1) is larger and proportionally wider than $\mathrm{m} 1$, the anterior wall of the crown is less convex, and the lingual flexid is proportionally larger. This tooth is remarkably similar to the $\mathrm{m} 2$ of the holotype of $L$. zeffiae. It differs only by having a sharper labial tip of the hypoconid, a little more penetrating hypoflexid, and more constrained lingual exit of the lingual valley.

Additionally, there are some differences between $L$. zeffiae and L. maior in the timing of closure and erasure of the lingual valleys. In the holotype of L. maior, the anterofossettid of $p 4$ is still present, whereas in the holotype of $L$. zeffiae and in referred specimens with comparatively less worn $\mathrm{m} 1$ and $\mathrm{m} 2$, this structure is already worn away (see Vucetich et al., 2014: fig. 5E-H). These differences could be the result of the differential wear on the p4 trigonid of MOZ-PV 969 mentioned above.

The lower incisor is broken posteriorly at the level of the $\mathrm{m} 2$, but owing to its implantation it seems to have been long, with its posterior end reaching at least a point behind $\mathrm{m3}$, as in L. zeffiae. Anteriorly, the tooth is broken at the level of the anterior portion of the diastema; at this point the cross section is nearly as wide $(1.45 \mathrm{~mm})$ as long, the distal face is convex, and the mesial one is straight.

As in the type species, the mandibular diastema is long and gently curved, the mental foramen is very large, rounded, close to the dorsal border of the diastema, and faces anteriorly, the notch for the tendon of the masseter medialis pars infraorbitalis is very poorly marked, and the masseteric crest rises at the level of anterior border of the m1 (Fig. 4.2). However, the mandibular ramus is proportionally more robust than in L. zeffiae; the masseteric crest is more salient and located higher in the mandible. 


\section{Discussion}

Other Paleogene-early Neogene caviomorphs also display an 8-shaped occlusal configuration of the lower molars, at least temporarily. However, Cephalomys Ameghino, 1897, and Litodontomys Loomis, 1914, are much more hypsodont, the enamel is typically reduced on the anterior wall of the molars, and the structure of $\mathrm{p} 4$ is radically different. The acaremyids Acaremys Ameghino, 1887a and Sciamys Ameghino, 1887a are more hypsodont, whereas in Galileomys Vucetich and Kramarz, 2003, and Platypitamys Wood, 1949 , the crowns are terraced and neither of them acquires an 8-shaped design. In the late Miocene octodontid Chasicomys Pascual, 1967, the premolars are not replaced. The structure of the $\mathrm{p} 4$ trigonid of L. maior resembles that of the isolated tooth tentatively referred to Banderomys (Kramarz, 2005: fig. 5C), recorded in the same levels of the Cerro Bandera Formation, but this taxon has more hypsodont and larger teeth, and the molars do not acquire an 8-shaped pattern with wear. Consequently, and although some minor differences could be identified, MOZ-PV 969 is much closer to the holotype of L. zeffiae than to any other known taxon with 8-shaped molars, and therefore the generic assignment herein proposed is the most reasonable one with the current evidence.

\section{CONCLUDING REMARKS}

The three species here described, Protypotherium sinclairi, Doryperimys olsacheri, and Leucokephalos maior, broaden the knowledge on notoungulate and caviomorph rodent diversity and distribution in northern Patagonia during the early Miocene.

The type and several specimens referred to $D$. olsacheri and the type of L. maior come from the same level of the Cerro Bandera Formation exposed on the northeastern slope of Barda Negra (BN1). The type of P. sinclairi was unearthed from isolated exposures of the same unit on the northwestern slope of Sierra del Portezuelo Norte (SPN), almost $25 \mathrm{~km}$ from Barda Negra, and the exact correlation with BN1 is uncertain. However, at least one specimen referable to $P$. sinclairi is derived from BN1, supporting the co-occurrence of the three species.

Accepting the transference of the Colhuehuapian Protypotherium minor to the genus Cochilius here proposed, $P$. sinclairi is the only nominal species of Protypotherium posi- tively recorded in pre-Santacrucian deposits. It differs from other species primarily by the lesser degree of reduction of the p3-p4 talonids. Reguero et al. (2003) and Reguero and Prevosti (2010) concluded that at least the reduction of the p3 talonid in Protypotherium and Miocochilius is the primitive condition among late-diverging interatheriids. However, such reduction is extreme in the late Miocene species and less pronounced in the Santacrucian species, suggesting that the condition observed in P. sinclairi is plesiomorphic compared with the remaining species of the genus. Thus, a revised analysis of interathere phylogeny at species level is required for a better understanding of the evolutionary meaning of this character.

Leucokephalos maior, only known by the holotype, is a small caviomorph with rooted cheek teeth with a vaguely 8-shaped occlusal design resembling that of some cephalomyids (Chinchilloidea?) and some extinct octodontoids. Its relationships with the main caviomorph clades are still uncertain, but whatever its proper systematic position, it is unambiguously close to the Cabeza Blanca species L. zeffiae, differing only by its larger size (see Tab. 4), some mandibular features, and minor dental details.

The chinchilloid Doryperimys displays a singular combination of dental characters, some shared with the species of Perimys and others with Scotamys antiquus. This taxon is unknown in other Miocene or Oligocene mammal associations, even much better sampled assemblages from southern and central Patagonia, and in those latitudinally closer and presumably coeval associations in northern Patagonia and Chile (i.e., Chichinales and Laguna del Laja, see Barrio et al., 1989; Kramarz et al., 2004; Flynn et al., 2008). The exclusive occurrence of Doryperimys, as well as other supposedly endemic rodents in deposits of the Cerro Bandera Formation (i.e., Garridomys Kramarz et al., 2012 and Banderomys Kramarz, 2005) reveals the distinctive character of this rodent assemblage.

The mammal-bearing deposits of the Cerro Bandera Formation were originally assigned to the early Miocene Colhuehuapian SALMA (Leanza and Hugo, 1997; Kramarz et al., 2005). The record in these levels of additional taxa described from older mammal assemblages has cast doubts on this biochronological assessment (see Kramarz et al., 2011 for a preliminary discussion). Furthermore, the known distribution of the taxa herein described provide ambiguous 
biochronological interpretations: Protypotherium species are only known for Colhuehuapian and younger associations, whereas Leukokephalos was previously known for the Deseadan Cabeza Blanca fauna. Efforts to obtain absolute dates from the Cerro Bandera Formation have been unfruitful to date because all sampled horizons are extremely pedogenized and/or bear altered glass and plagioclase (Heizler, pers. comm.). A complete discussion of the chronological meaning and paleobiogeographic implications of this mammal assemblage is pending an integrative paleontological and stratigraphic study still in progress, which includes the findings reported here and numerous new fossil-mammal materials from the Cerro Bandera Formation and other Miocene deposits in northern Patagonia.

\section{ACKNOWLEDGMENTS}

We thank A. Garrido (MOZ), A. Forasiepi (IANIGLIA-CCT), L. Filippi, S. Saldivia (Museo Carmen Funes), A. Martinelli, and G. Aguirrezabala for their help during the fieldtrips; R. Coria (Museo Carmen Funes) and Dirección Provincial de Minería de la Provincia del Neuquén for technical support during fieldworks. A. Garrido helped with the edition of the Figure 1. We would also like to thank $G$. Vucetich and R. Hitz for their very helpful comments and corrections. This work is a contribution to the projects PIP CONICET 6018/05 and 0276/2011.

\section{REFERENCES}

Ameghino, F. 1885. Nuevos restos de mamíferos oligocenos recogidos por el Profesor Pedro Scalabrini y pertenecientes al Museo Provincial de la ciudad de Paraná. Boletín de la Academia Nacional de Ciencias en Córdoba 8: 5-207.

Ameghino, F. 1887a. Enumeración sistemática de las especies de mamíferos fósiles coleccionados por Carlos Ameghino en los terrenos eocenos de Patagonia austral y depositados en el Museo de La Plata. Boletín del Museo de La Plata 1: 1-26.

Ameghino, F. 1887b. Observaciones generales sobre el orden de mamíferos extinguidos Sud-Americanos llamados toxodontes (Toxodontia) y sinopsis de los géneros y especies hasta ahora conocidos. Anales del Museo de La Plata (Entrega especial, 1936): 1-66.

Ameghino, F. 1889. Contribución al conocimiento de los mamíferos fósiles de la República Argentina. Actas de la Academia Nacional de Ciencias en Córdoba 6: 1-1027.

Ameghino, F. 1891. Nuevos restos de mamíferos fósiles descubiertos por Carlos Ameghino en el Eoceno inferior de la Patagonia austral. Nuevas especies, adiciones y correcciones. Revista Argentina de Historia Natural 1: 289-328.

Ameghino, F. 1894. Enumération synoptique des espèces de mammifères fossiles des formations éocènes de Patagonie. Boletín de la Academia Nacional de Ciencias de Córdoba 13: 259-452.

Ameghino, F. 1897. Mammifères crétacés de l’Argentine. Deuxième contribution à la connaissance de la faune mammalogique des couches à Pyrotherium. Boletín Instituto Geográfico Argentino 18: 406-429, 431-521.

Ameghino, F. 1902. Première contribution à la connaissance de la faune mammalogique des couches à Colpodon. Boletín de la
Academia Nacional de Ciencias en Córdoba 17: 71-138.

Barrio, C., Carlini, A., and Goin, F. 1989. Litogénesis y antigüedad de la Formación Chichinales de Paso Córdoba (Río Negro, Argentina). $2^{\circ}$ Congreso Argentino de Paleontología y Bioestratigrafía (Mendoza), Actas 4: 149-156.

Bordas, A.F. 1939. Diagnosis sobre algunos mamíferos de las capas con Colpodon del valle del río Chubut (República Argentina). Physis 14: 413-433.

Bowdich, T.E. 1821. An analysis of the natural classifications of Mammalia for the use of students and travellers. J. Smith ed., Paris, $115 \mathrm{p}$.

Cabrera, A., and Kraglievich, L. 1931. Diagnosis previas de los ungulados fósiles de Arroyo Chasicó. Notas Preliminares del Museo de La Plata 1: 107-113.

Cione, A.L., Azpelicueta, M.M., Bond, M., Carlini, A.A., Casciota, J.R., Cozzuol, M.A., de la Fuente, M., Gasparini, Z., Noriega, J.I., Scillato-Yané, G.J., Soibelson, L., Tonni, E.P., Verzi, D., and Vucetich, M.G. 2000. Miocene vertebrates from Entre Ríos, eastern Argentina. In: F.G. Aceñolaza, and R. Herbst (Eds.), El Neógeno de Argentina. Instituto Superior de Correlación Geológica (INSUGEO), San Miguel de Tucumán, p. 191-237.

Croft, D.A., Anaya, F., Auerbach, D., Garzione, C., and MacFadden, B.J. 2009. New data on Miocene Neotropical Provinciality from Cerdas, Bolivia. Journal of Mammalian Evolution 16: 175-198.

Dunn, R.E., Madden, R.H., Kohn, M.J., Schmitz, M.D., Stromberg, C.A.E., Carlini, A.A., Ré, G.H., and Crowley, J. 2013. A new chronology for middle Eocene-early Miocene South American Land Mammal Ages. Geological Society of America, Bulletin 125: 539-555.

Flynn, J.J., Novecek, M.J., Doson, H.E., Frassinetti, D., McKenna, M.C., Norell, M.A., Sears, K.E., Swisher, III, C.C., and Wyss, A.R. 2002. A new fossil mammal assemblage from the southern Chilean Andes: implications for geology, geochronology, and tectonics. Journal of South American Earth Sciences 15: 285-302.

Flynn, J.J., Charrier, R., Croft, D.A., Gans, P.B., Heriott, T.M., Wertheim, J.A., and Wyss, A.R. 2008. Chronologic implications of new Miocene mammals from the Cura-Mallin and Trapa Trapa formations, Laguna del Laja region, south central Chile. Journal of South American Earth Sciences 26: 412-423.

Kraglievich, L. 1926. Los grandes roedores terciarios de la Argentina y sus relaciones con ciertos géneros pleistocenos de las AntiIlas. Anales del Museo Nacional de Historia Natural 34: 121-135.

Kramarz, A.G. 2002. Roedores chinchilloideos (Hystricognathi) de la Formación Pinturas, Mioceno temprano-medio de la provincia de Santa Cruz, Argentina. Revista del Museo Argentino de Ciencias Naturales 4: 167-180.

Kramarz, A.G. 2005. A primitive cephalomyid hystricognath rodent from the early Miocene of northern Patagonia, Argentina. Acta Palaeontologica Polonica 50: 249-258.

Kramarz, A.G., and Bond, M. 2011. New Early Miocene astrapotheriid (Mammalia, Astrapotheria) from Northern Patagonia, Argentina. Neues Jahrbuch für Geologie und Paläontologie 260: 277-287.

Kramarz, A., and Paz, E.R. 2013. Un Hegetotheriidae (Mammalia, Notoungulata) basal del Mioceno temprano de Patagonia. Revista Mexicana de Ciencias Geológicas 30: 186-195.

Kramarz, A., Garrido, A., Ribeiro, A.M., and Ortiz, R. 2004. Nuevos registros de vertebrados fósiles de la Formación Chichinales, Mioceno Temprano de la provincia de Río Negro. Ameghiniana, Suplemento Resúmenes 41: 53R.

Kramarz, A., Garrido, A., Forasiepi, A., Bond, M., and Tambussi, C. 2005. Estratigrafía y vertebrados (Mammalia-Aves) de la Formación Cerro Bandera, Mioceno Temprano de la provincia del Neuquén, Argentina. Revista Geológica de Chile 32: 273-291. 
Kramarz, A., Tejedor, M., Forasiepi, A., and Garrido, A. 2011. New early Miocene primate fossils from Northern Patagonia, Argentina. Journal of Human Evolution 62: 186-189.

Kramarz, A., Vucetich, M.G., and Arnal, M. 2012. A new early Miocene chinchilloid hystricognath rodent; an approach to the understanding of the early chinchillid dental evolution. Journal of Mammalian Evolution 20: 249-261.

Lane, H.H. 1927. A new protypothere from the Santa Cruz Formation of Patagonia. University of Kansas, Sciences Bulletin 17: 313-317.

Leanza, H.A., and Hugo, C.A. 1997. Hoja geológica 3969-III Picun Leufú. SEGEMAR, Buenos Aires, Boletín 218: 1-135.

Loomis, F.B. 1914. The Deseado Formation of Patagonia. Rumford Press, Amherst, $232 \mathrm{p}$.

Pascual, R. 1967. Los roedores Octodontoidea (Caviomorpha) de la Formación Arroyo Chasicó (Plioceno inferior) de la Provincia de Buenos Aires. Revista del Museo de La Plata 5: 259-282.

Reguero, M., and Prevosti, F.J. 2010. Rodent-like notoungulates (Typotheria) from Gran Barranca, Chubut Province, Argentina: Phylogeny and systematics. In: R.H. Madden, A.A. Carlini, M.G. Vucetich, and R.F. Kay (Eds.), The Paleontology of Gran Barranca: Evolution and Environmental Change through the Middle Cenozoic of Patagonia. Cambridge University Press, New York, p. 152-162.

Reguero, M., Ubilla, M., and Perea, D. 2003. A new species of Eopachyrucos (Mammalia, Notoungulata, Interatheriidae) from the Late Oligocene of Uruguay. Journal of Vertebrate Paleontology 23: 445-457.

Roth, S. 1903. Noticias preliminares sobre nuevos mamíferos fósiles del Cretáceo superior y Terciario inferior de la Patagonia. Revista del Museo de La Plata 11: 133-158.

Scott, W.B. 1905. Mammalia of the Santa Cruz beds. Volume V, Paleontology. Part III, Glires. In: W.B. Scott (Ed.), Reports of the Princeton University expeditions to Patagonia 1896-1899. E. Schweizerbart'sche Verlagshandlung (E. Nägele), Stuttgart, p. 348-487.

Sinclair, W.J. 1909. Mammalia of the Santa Cruz Beds. Volume VI, Paleontology. Part I, Typotheria. In: W.B. Scott (Ed.), Reports of the Princeton University expeditions to Patagonia 1896-1899. E. Schweizerbart'sche Verlagshandlung (E. Nägele), Stuttgart, p. $1-110$.

Stirton, R.A. 1953. A new genus of interatheres from the Miocene of Colombia. University of California Publications in Geological Sciences 29: 265-348.

Tauber, A.A. 1996. Los representantes del género Protypotherium (Mammalia, Notoungulata, Interatheriidae) del Mioceno Temprano de la Provincia de Santa Cruz, Argentina. Academia Nacional de Ciencias (Córdoba, Argentina), Misceláneas 995: 1-30.

Teruggi, M.E., Mazzoni, M.M., Spalletti, L.A., and Andreis, R.R. 1978. Rocas Piroclásticas. Interpretación y Sistemática. Asociación
Geológica Argentina. Publicaciones Especiales Serie B (Didáctica y Complementaria) 5: 1-36.

Tullberg, T. 1899. Ueber das System der Nagethiere: eine phylogenetische Studie. Nova Acta Regiae Societatis Scientiarum Upsaliensis 3: 1-514.

Vucetich, M.G., and Bond, M. 1984. Un nuevo Octodontoidea (Rodentia, Caviomorpha) del Oligoceno tardío de la Provincia de Chubut (Argentina). Ameghiniana 21: 105-114.

Vucetich, M.G., and Kramarz, A.G. 2003. New Miocene rodents of Patagonia (Argentina) and their bearing in the early radiation of the octodontiform octodontoids. Journal of Vertebrate Paleontology 23: 435-444.

Vucetich, M.G., and Verzi, D.H. 1996. A peculiar octodontoid (Rodentia, Caviomorpha) with terraced molars from the lower Miocene of Patagonia (Argentina). Journal of Vertebrate Paleontology 16: 297-302.

Vucetich, M.G., Kramarz, A.G., and Candela, A.M. 2010. The Colhuehuapian rodents from Gran Barranca and other Patagonian localities: the state of the art. In: R.H. Madden, A.A. Carlini, M.G. Vucetich, and R.F. Kay (Eds.), The Paleontology of Gran Barranca: Evolution and Environmental Change through the Middle Cenozoic of Patagonia. Cambridge University Press, New York, p. 206219.

Vucetich, M.G., Dozo, M.T., Arnal, M., and Pérez, M.E. 2014. New rodents (Mammalia) from the late Oligocene of Cabeza Blanca (Chubut) and the first rodent radiation in Patagonia. Historical Biology 27: 236-257.

Wood, A.E. 1949. A new Oligocene rodent genus from Patagonia. American Museum Novitates 1435: 1-54.

doi: 10.5710/AMGH.27.06.2015.2906

Submitted: March 20th, 2015

Accepted: June $27^{\text {th }}, 2015$ 